\title{
Comparison of subcutaneous inflammatory response to commercial and engineered zinc hydroxyapatite implants in rabbits
}

\author{
[Comparação da resposta inflamatória subcutânea aos implantes de \\ hidroxiapatita comercial e modificada com zinco em coelhos] \\ L.C. Muñoz ${ }^{1}$, S. Cardona.-Ramirez ${ }^{1,2^{*}}$, R.F. Silva ${ }^{1}$ \\ ${ }^{1}$ Universidad de Caldas - Manizales, Colombia \\ ${ }^{2}$ University of Missouri - Columbia, USA
}

\begin{abstract}
Hydroxyapatite (HA) is widely used as a biomaterial for bone repair and metallic prostheses coating. The main limitations of the current commercial synthetic hydroxyapatite compounds

include high cost and decreased availability, especially for veterinary medicine purposes. Additionally, it is thought that HA biocompatibility and bioactivity could be enhanced by the addition of metal compounds. The objective of this work was to compare the subcutaneous tissue response of commercial and engineered hydroxyapatite obtained from the bovine femur diaphysis mixed with different concentrations of hexa-hydrated Zinc Nitrate in rabbits. Twenty-Five New Zealand female rabbits were used. Five treatments were done according to HA composition (commercial HA, no Zn-HA, $0.1 \mathrm{M} \mathrm{Zn}$, $0.2 \mathrm{M} \mathrm{Zn}$, and $0.3 \mathrm{M} \mathrm{Zn}$ ). Each treatment was evaluated at five time-points $(8,15,30,60$ and 90 days postimplantation). Histopathologic analysis was performed to assess inflammation by polymorphonuclear cells infiltration, neovascularization, and fibrosis. Results obtained in this work suggest that general inflammation decreased after 60 days of implantation regardless of $\mathrm{Zn}$ concentration. Fibrosis score was increased in the commercial HP compared to control and Zn-hydrated HA. This paper shows that bovine hydroxyapatite is a biocompatible material regardless of nitrate Zinc concentration and has the same properties of commercial hydroxyapatite.
\end{abstract}

Keywords: animal model, biocompatibility, bone, integration

\section{RESUMO}

A hidroxiapatita (HA) é amplamente utilizada como biomaterial para reparo ósseo e revestimento de próteses metálicas. As principais limitações dos atuais compostos comerciais de hidroxiapatita sintética incluem alto custo e menor disponibilidade, especialmente para fins de medicina veterinária. Além disso, acredita-se que a biocompatibilidade e a bioatividade da HA poderiam ser aumentadas pela adição de compostos metálicos. O objetivo deste trabalho foi comparar a resposta tecidual subcutânea de hidroxiapatita comercial e da obtida da diáfise do fêmur bovino misturada com diferentes concentrações de nitrato de zinco hexa-hidratado em coelhos. Foram utilizadas 25 coelhas fêmeas Nova Zelândia. Cinco tratamentos foram feitos de acordo com os compostos de HA (HA comercial, no Zn-HA, o, 1M Zn, $0,2 \mathrm{M} Z \mathrm{Zn}$ e 0,3M Zn). Cada tratamento foi avaliado em cinco momentos (oito, 15, 30, 60 e 90 dias após a implantação). A análise histopatológica foi realizada para avaliar a inflamação por infiltração de células polimorfonucleares, neovascularização e fibrose. Os resultados obtidos neste trabalho sugerem que a inflamação geral diminuiu após 60 dias de implantação, independentemente da concentração de $\mathrm{Zn}$. O escore de fibrose foi aumentado na HA comercial comparada com o controle e com a HA hidratada com Zn. Este trabalho mostra que a hidroxiapatita bovina é um material biocompatível independentemente da concentração de nitrato de zinco e possui as mesmas propriedades da hidroxiapatita comercial.

Palavras-chave: modelo animal, biocompatibilidade, osso, integração

Recebido em 13 de março de 2019

Aceito em 7 de junho de 2019

*Autor para correspondência (corresponding author)

E-mail: scardonaramirez@mail.missouri.edu 


\section{INTRODUCTION}

Musculoskeletal trauma is a common source of bone loss, mainly associated with open fractures (Keating et al., 2005). Lower limb fractures are common among active men and women (Hootman et al., 2002). Therapeutic intervention often includes the use of autografts and allografts; however, donor site morbidity and adverse immune response are common weaknesses of these methods (Hootman et al., 2002; Keating et al., 2005; Mauffrey et al., 2012). It has been shown that hydroxyapatite (HA) improves bone tissue regeneration (Swetha et al., 2010). Nevertheless, HA limitations include biomechanical disadvantages such as poor resistance to torsional bending stresses (Keating et al., 2005). It is hypothesized that the incorporation of $\mathrm{Zn}$ into HA matrix would increase osteoblast bioactivity, leading to improved bone formation and higher biological properties (Thian et al., 2013).

Ceramic application has evolved significantly in recent years (Vallet-Regí and González-Calbet, 2004). They are widely used in musculoskeletal tissue repair and regeneration, due to its resistance to $\mathrm{pH}$ changes and high temperatures. Additionally, bioceramics show better tissue responses compared with polymers or metals. Apatite is one of the most common used ceramics and has shown great ability to bind to the bone (Yang et al., 2011). Due to its similarity with the mineral phase of the bone, HA can restore osseous systems. Currently, common uses of HA include knee, hip, elbow and tooth roots (Yang et al., 2011).

Compatibility with host tissues remains the main concern when using new biomaterials. Cytotoxicity, hypersensitivity, carcinogenicity and biodegradation are listed as the main features affecting biocompatibility (Brown et al., 1995; Kimber et al., 2001; Christenson et al., 2005; Knight et al., 2006; Biological..., 2009). The first step to assess the biological response to any implanted material is the biological response to host tissues, specifically in subcutaneous tissue. The International Society for Standardization (ISO) recommendations for biocompatibility in biomedical devices (IS0 10993-6, 2016) suggest comparing different conditions or variations of the same material along with the comparison to a control material (Biological..., 2009). Therefore, the purpose of this work was to assess the subcutaneous response to different concentrations of $\mathrm{Zn}-\mathrm{HA}$ compared to commercially available HA in rabbits.

\section{MATERIALS AND METHODS}

With institutional approval, twenty-five New Zealand female rabbits were used. Five treatments were done according to Zinc Nitrate concentration (from left to right commercial HA (IngeniOs ${ }^{\mathrm{TM}}$ HA Zimmer Dental Inc., Carlsbad, CA) (control), pure HA (no $\mathrm{Zn}$ addition), and three $\mathrm{Zn}$ treated $\mathrm{HA}$ compounds containing $0.1 \mathrm{M}, 0.2 \mathrm{M}$, and $0.3 \mathrm{M} \mathrm{Zn}$ nitrate). Each treatment was evaluated at five time-points (8, 15, 30, 60 and 90 days). Five dermal pockets were made by $1 \mathrm{~cm}$ surgical incision in the left side of the skin in the dorsal thoracic zone (from the shoulder to the iliac apophysis). 60mg of every treatment (HA different concentration) were placed on each pocket and replicated on the right side for a total of 10 implantation sites (Figure 1).

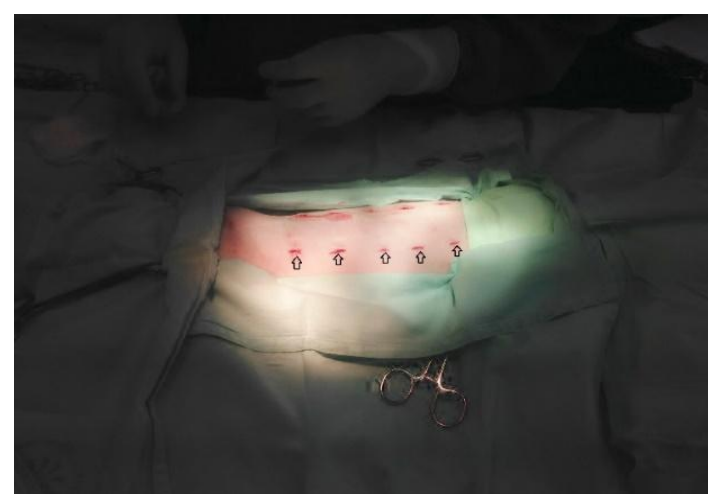

Figure 1. Surgical area and implant sites. Arrows show five treatment dermal pockets.

Bones obtained from bovine femur diaphysis were heated in water $\left(160^{\circ} \mathrm{C}\right)$ for 6 hours, then $1 \mathrm{~cm}^{3}$ bone pieces were cut. After that, calcination was achieved by different temperatures $\left(600^{\circ} \mathrm{C}, 800^{\circ} \mathrm{C}, 1000^{\circ} \mathrm{C}\right.$ y $\left.1050^{\circ} \mathrm{C}\right)$ for 3 hours and $5^{\circ} \mathrm{C} /$ minute. HA samples were smashed and analyzed by X-ray diffraction, Raman spectroscopy, and atomic absorption spectroscopy. Ionic exchange technique was used for incorporation of $\mathrm{Zn}\left(0.1 \mathrm{M}\left[\mathrm{Zn}\left(\mathrm{NO}_{3}\right)_{26} \mathrm{H}_{2} \mathrm{O}\right]\right)$, and was kept with $10 \mathrm{~g}$ HA, slightly agitated for $48 \mathrm{~h}$ at $32^{\circ} \mathrm{C}$. The resulting solution was filtered and dried at $100^{\circ} \mathrm{C}$ for $24 \mathrm{~h}$ and after that calcined at $350^{\circ} \mathrm{C}$ for $3 \mathrm{~h}$. 
Histopathology analysis was performed in order to detect tissue response to the implanted biomaterial. A piece of cutaneous tissue was taken $\left(1 \mathrm{~cm}^{3}\right)$ from each implantation site and was fixed in $10 \%$ formaldehyde buffered solution until analysis. Samples were further dehydrated in serial alcohol dilutions and embedded in paraffin. 5-6 $\mu \mathrm{m}$ sections were cut and stained with Hematoxylin and Eosin $(\mathrm{H} \&$ E). To assess biocompatibility, macroscopic and microscopic evaluation was performed in accordance to the international guidelines for biological evaluation of medical devices-tests for local effects after implantation- (ISO 10993-62009). Assessment of inflammation by polymorphonuclear cells infiltration (PMN), neovascularization (NVASC), and fibrosis (FIB) were evaluated according to a visual analogue scale (VAS) with four different grades (Biological..., 2009) (Figure 2, 3 and 4).

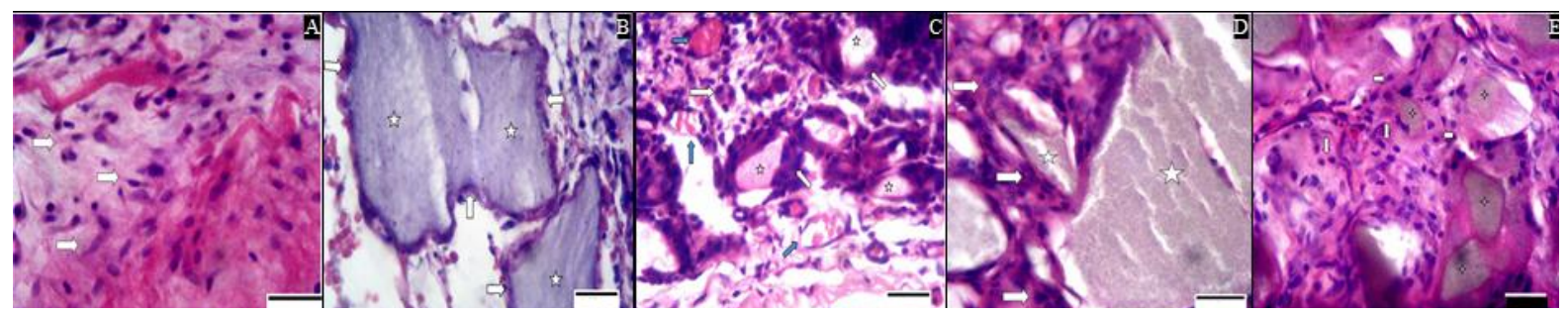

Figure 2. Histopathologic analysis of different treatment groups at 8 days post-operative. A) Control; B) PHA; C) HA0.1; D) HA0.2 E) HA0.3. White arrows indicate giant cell infiltration (A), Fibrosis surrounding the biomaterial (stars), blue arrows indicate congested blue vessels. Scale bar: 50 $\mathrm{m}$.

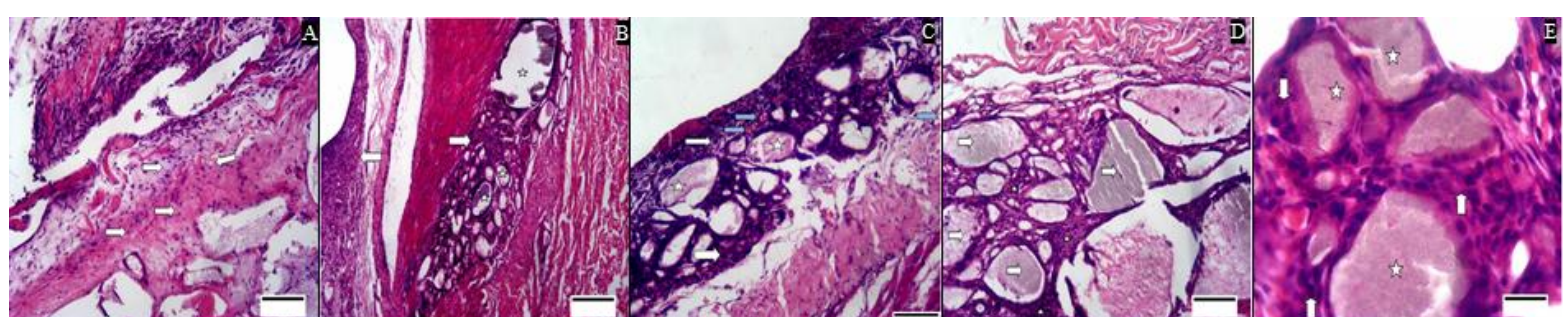

Figure 3. Histopathologic analysis of different treatment groups at 15 days post-operative. A) Control; B) PHA; C) HA0.1; D) HA0.2 E) HA0.3. White arrows indicate giant cell infiltration (A, C, D), Inflammatory reaction $(\mathrm{B}, \mathrm{E})$ stars indicate biomaterial surface, blue arrows indicate congested blood vessels (C). Scale bar: $50 \mu \mathrm{m}$.

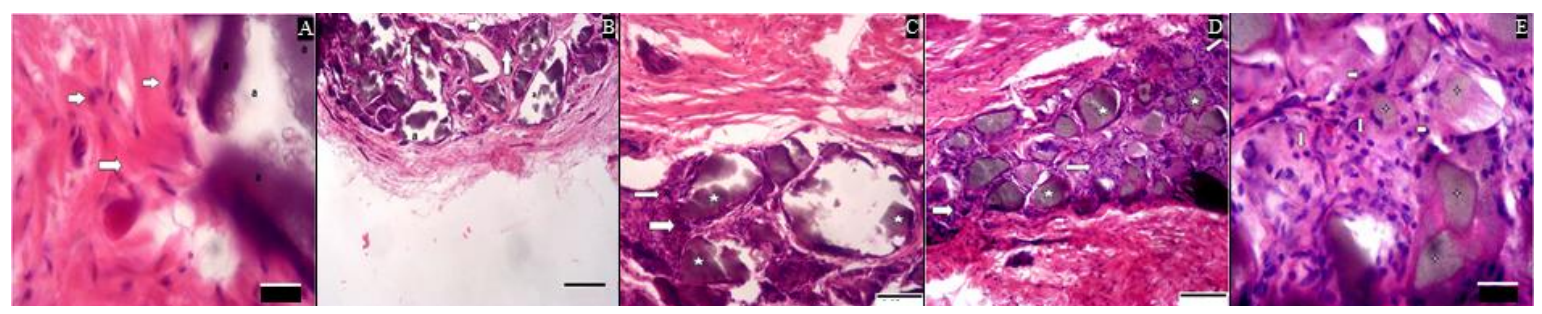

Figure 4. Histopathologic analysis of different treatment groups at 90 days post-operative. A) Control; B) PHA; C) HA0.1; D) HA0.2 E) HA0.3. White arrows indicate fibrosis in hypodermis and subcutaneous

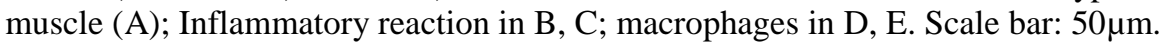

\section{RESULTS}

Present results show that addition of $0.1 \mathrm{M}$ of $\mathrm{Zn}$ nitrate lead to a higher PMN cells infiltration the first 8 days after implantation compared to the other treatments (Figure 5A). Interestingly, the addition of $\mathrm{Zn}$ to HA compound show no PMN infiltration on day 60 after implantation (Figure 5C). Interestingly, PMN counts show similar results compared to commercial HA (control) on day 15 (Figure 5B). Additionally, PHA and HA0.1 showed lower PMN counts on days 30, 60 and 90 (Figure 5C-E). 
Histopathologic grading showed that neovascularization score (NVASC) was lower when $0.1 \mathrm{M}$ of $\mathrm{Zn}$ nitrate was added to the HA compound. Interestingly, control HA lead to a higher capillary formation on day 60 compared to HA compounds treated with $\mathrm{Zn}$ nitrate (Figure 5I). Additionally, all HA compounds showed no capillary formation on day 90 (Figure $5 \mathrm{~J}$ ). Furthermore, commercial HA compound showed no significant differences compared to pure HA (no $\mathrm{Zn}$ nitrate addition) better scores compared to control on days 15 and 60 (Figure 5F-J).

Fibrosis score decreased significantly after 90 days of implantation only in the control group (Figure $5 \mathrm{~K}-\mathrm{O}$; Figure $6 \mathrm{C}$ ). Additionally, results showed that the addition of $0.2 \mathrm{M}$ of $\mathrm{Zn}$ nitrate to HA compound decreased fibrosis after 60 days of implantation (Figure 5N). However, this was no different from other Zn-treated HA compounds at day 90 post-implantation (Figure $5 \mathrm{O})$. Furthermore, the addition of $0.2 \mathrm{M}$ of $\mathrm{Zn}$ nitrate to HA compounds, significantly decreased fibrosis score on days 15 and 60 after implantation compared to commercial HA (control) (Figure 5L,N). Interestingly, the addition of $\mathrm{Zn}$ nitrate decreased fibrosis after 90 days of implantation compared to no addition of $\mathrm{Zn}$ nitrate to HA compound (PHA) (Figure 5O). Surprisingly, commercial HA on day 90 showed a lower fibrosis score compared to control HA (Figure 5O). Finally, addition of $\mathrm{Zn}$ nitrate to HA compounds did not show significant differences compared to control HA after 90 days of implantation (Figure 5E, J, O), showing acceptable overall biocompatibility. Scanning electron microscopy (SEM) showed integration of the biomaterial with host tissues (Figure 6).
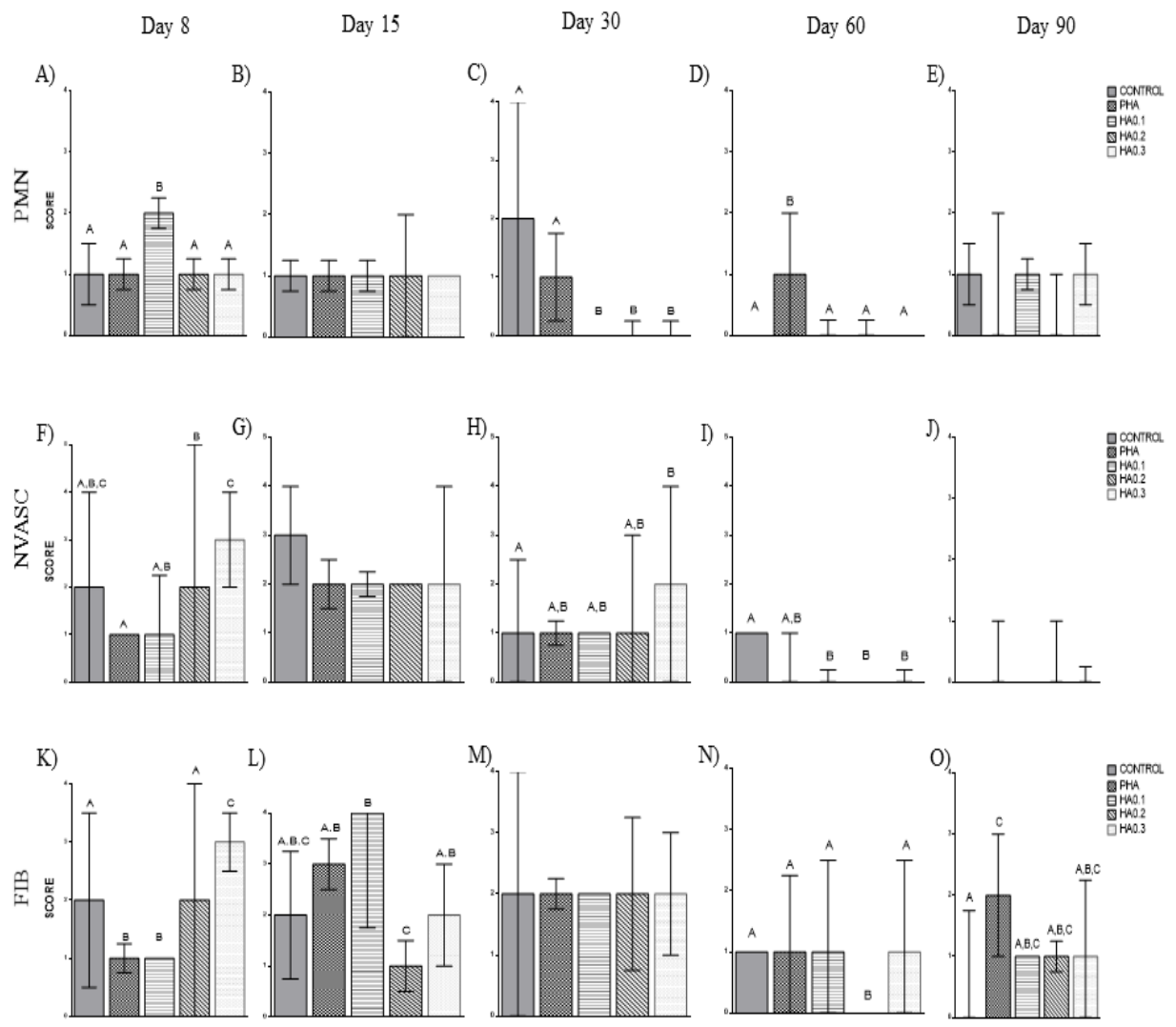

Figure 5. Inflammation score at five different time points.

PMN: Polymorphonuclear cells; NVASC: Neovascularization; FIB: Fibrosis. Groups with different letters denote statistical difference. 


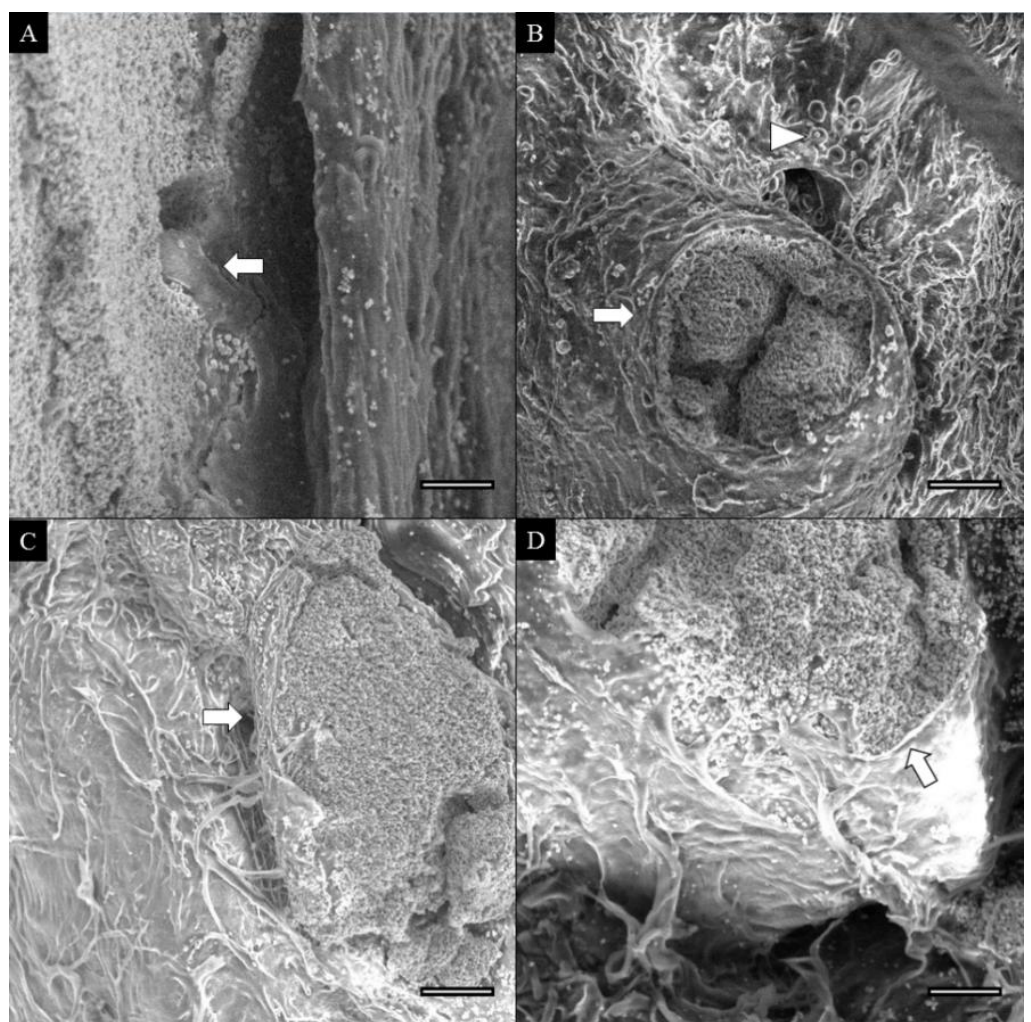

Figure 6. Scanning electron microscopy of engineered HA integration with host tissue.

Different tissue responses to the implantation of the biomaterial are shown. A: PHA; B: 0.1M Zn; C: $0.2 \mathrm{M} Z \mathrm{Zn}$; D: 0.3M Zn. Arrows: Tissue-HA interface. Arrowhead: erythrocytes. Scale bar: $20 \mu \mathrm{m}$.

\section{DISCUSSION}

Acute inflammation is characterized by the presence of neutrophils in the implantation site and generally lasts from 48 hours to almost a week in the implant-tissue interphase (Anderson et al., 2008). Phagocytic activity in the first days after surgery determines HA biodegradation (Grote et al., 1986, Ye et al., 2001). PMN cells allow optimal healing and tissue regeneration. Results presented in this work are in accordance with other authors and are demonstrated by the presence of initial inflammation in all the evaluated implantation sites. Habraken et al. (2010), showed that calcium phosphates compounds can be used as scaffolds for tissue regeneration promoting initial inflammation. However, since the initial response could be due to the surgical procedure itself, careful interpretation is suggested (Nagase et al., 1988). Additionally, it has been shown that inflammation could last more than expected due to a protective effect of the immune system, but it should resolve with time (VandeVord et al.,
2002). Interestingly, at 90 days after surgery, pure and commercial HA acquired similar PMN counts, regardless of $\mathrm{Zn}$ addition which shows that the HA obtained from bovine diaphysis, had similar biocompatibility.

Regarding neovascularization, results presented in this work showed high initial scores for both commercial and pure HA that decrease over time and reach similar levels on day 90 . This finding suggests a good healing response based on the granulation tissue formation and regeneration (Anderson et al., 2008). It can also explain an increased biocompatibility in all treatments at the end of the experiment where no significant differences between control and treatments were found. Some authors have demonstrated that HA induces angiogenesis, due to growth factors release, especially VEGF, which stimulates new capillary formation in surrounding tissues (Traini et al., 2006, Lima et al., 2006). Our findings are in accordance with Lima et al. (2006) who showed that angiogenesis increased only two weeks after implantation. 
According to Bell and Beirne (1988), the fibrosis in the implant-tissue interphase is a biocompatibility criteria and the presence of mature connective tissue indicates a successful integration with the host tissues (WierzbickaPatynowski and Schwarzbauer, 2003). Fibrin acts as the main scaffold for collagen and clot formation (Nieswandt and Offermanns 2004) and leads to adequate levels of fibronectin, responsible for endothelial platelet adhesion (Luttikhuizen et al., 2006). Some authors suggest that fibrosis along with other pathobiological processes like acute inflammation and granulation tissue formation are common features after material implantation and help improve healing and biological degradation of HA (Bell and Beirne, 1988; Gretzer et al., 2006). In this work, we were able to show that although fibrosis is increased with the addition of $0.2 \mathrm{M}$ and $0.3 \mathrm{M}$ hexa-hydrated $\mathrm{Zn}$ at the beginning of the experiment, it decreases to a lower stage by 90 days of implantation, being similar to control and commercial HA.

Weaknesses in this study include the lack of complimentary molecular techniques including immunohistochemistry methods (IHC), gene and protein expression of biomarkers involved in direct and indirect healing (PCR, ELISA, WB) and the inability to use quantitative instead of subjective evaluation. Therefore, careful analysis of present results is advised. However, results obtained from this study show promising results due to the initial increasing in fibrosis score at day 15 and 30 post-implantation. These findings are in accordance with other authors that describe the presence of mature connective tissue in the material-tissue interphase as an indicator of good implantation and healing response (Bell and Beirne 1988). Although synthetic HA fibrosis was higher on day 90 post-implantation compared to control HA, resorption is expected later, hence, longer time-point studies are strongly suggested.

\section{CONCLUSIONS}

Results of the present work show that HA obtained from bovine femur is a biocompatible material and produces a similar subcutaneous response compared to commercially available HA. The addition of $0.2 \mathrm{M}$ of $\mathrm{Zn}$ nitrate improves the inflammatory response by decreasing PMN cell counting. Additionally, neovascularization was similar after 90 days of implantation in all of the materials regardless of $\mathrm{Zn}$ addition. Finally, it appears that commercial HA require 90 days for complete degradation shown by complete removal of fibrosis. Nevertheless, bovine HA and the addition of $\mathrm{Zn}$ nitrate to this compound may require a longer time for complete integration.

\section{REFERENCES}

ANDERSON, J.M.; RODRIGUEZ, A.; CHANG D.T. Foreign body reaction to biomaterials. Semin. Immunol., v.20, p.86-100, 2008.

BELL, R.; BEIRNE, O.R. Effect of hydroxylapatite, tricalcium phosphate, and collagen on the healing of defects in the rat mandible. J. Oral Maxillofac. Surg., v.46, p.589594, 1988.

BIOLOGICAL evaluation of medical devices. Part 6: Tests for local effects after implantation. Geneva: ISO, 2016.

BROWN, N.A.; SPIELMANN, H.; BECHTER $\mathrm{R}$. et al. Screening chemicals for reproductive toxicity: the current alternatives. Altern. Lab. Anim., v.23, p.868-882, 1995.

CHRISTENSON, E.M.; DADSETAN, M.; ANDERSON, J.M. et al. Biostability and macrophage-mediated foreign body reaction of silicone-modified polyurethanes. J. Biomed. Mater. Res. part A, v.74, p.141-155, 2005.

GRETZER, C.; EMANUELSSON, L.; LILJENSTEN, E. et al. The inflammatory cell influx and cytokines changes during transition from acute inflammation to fibrous repair around implanted materials. J. Biomater. Sci. Polym. ed., v.17, p.669-687, 2006. GROTE, J.J.; VAN BLITTERSWIJK, C.A.; KUIJPERS, W. Hydroxyapatite ceramic as middle ear implant material: animal experimental results. Ann. Otol. Rhinol. Laryngol. Suppl., v.123, p.1-5, 1986.

HABRAKEN, W.J.; LIAO, H.B.; ZHANG, Z. et al. In vivo degradation of calcium phosphate cement incorporated into biodegradable microspheres. Acta Biomater., v.6, p.2200-2211, 2010. 
HOOTMAN, J.M.; MACERA, C.A.; AINSWORTH B.E. et al. Epidemiology of musculoskeletal injuries among sedentary and physically active adults. Med. Sci. Sports Exerc., v.34, p.838-844, 2002.

KEATING, J.F.; SIMPSON, A.H.R.W.; ROBINSON, C.M. The management of fractures with bone loss. J. Bone Joint Surg. Br., v.87, p.142-150, 2005.

KIMBER, I.; BASKETTER, D.; BERTHOLD, $\mathrm{K}$. et al. Skin sensitization testing in potency and risk assessment. Toxicol. Sci., v.59, p.198-208, 2001.

KNIGHT, A.; BAILEY, J.; BALCOMBE, J. Animal carcinogenicity studies: 1. Poor human predictivity. Altern. Lab. Anim., v.34, p.19-27, 2006.

LEACH, J.K.; KAIGLER, D; WANG, Z. et al. Coating of VEGF-releasing scaffolds with bioactive glass for angiogenesis and bone regeneration. Biomaterials, v.27, p.3249-3255, 2006.

LIMA, I.R.; COSTA, A.M.; BASTOS, I.N. et al. Development and characterization of $5 \% \mathrm{~mol} \mathrm{Zn}$ bioceramic in granular form. Mater. Res., v.9, p.399-403, 2006.

LUTTIKHUIZEN, D.T.; HARMSEN, M.C.; VAN LUYN, M.J. Cellular and molecular dynamics in the foreign body reaction. Tissue Eng., v.12, p.1955-1970, 2006.

MAUFFREY, C.; MADSEN, M.; BOWLES, R.J. et al. Bone graft harvest site options in orthopaedic trauma: a prospective in vivo quantification study. Injury, v.43, p.323-326.

NAGASE, M.; BAKER, D.; SCHUMACHER Jr., H. Prolonged inflammatory reactions induced by artificial ceramics in the rat air pouch model. J. Rheumatol., v.15, p.1334-1338, 1988.
NIESWANDT, B.; OFFERMANNS, S. Pharmacology of platelet adhesion and aggregation. Handb. Exp. Pharmacol., v.165, p.437-471, 2004.

SWETHA, M.; SAHITHI, K.; MOORTHI, A. et al. Biocomposites containing natural polymers and hydroxyapatite for bone tissue engineering. Int. J. Biol. Macromol. v.47, p.1-4, 2010.

THIAN, E.S.; KONISHI, T.; KAWANOBE, Y. et al. Zinc-substituted hydroxyapatite: a biomaterial with enhanced bioactivity and antibacterial properties. J. Mater. Sci. Mater. Med., v.24, p.437-445, 2013.

TRAINI, T.; ASSENZA, B.; SAN ROMAN, F. et al. Bone microvascular pattern around loaded dental implants in a canine model. Clin. Oral Investig., v.10, p.151-156, 2006.

VALLET-REGÍ, M.; GONZÁLEZ-CALBET, J.M. Calcium phosphates as substitution of bone tissues. Prog. Solid State Chem., v.32, p.1-31, 2004.

VANDEVORD, P.J.; MATTHEW, H.W.; DESILVA, S.P. et al. Evaluation of the biocompatibility of a chitosan scaffold in mice. J. Biomed. Mater. Res. Part A. v.59, p.585-590, 2002.

WIERZBICKA-PATYNOWSKI, I.; SCHWARZBAUER, J.E. The ins and outs of fibronectin matrix assembly. J. Cell Sci., v.116, p.3269-3276, 2003.

YANG, Y.; KANG, Y.; SEN, M. et al. Bioceramics in tissue engineering. In: BURDICK J.A.; MAUCK R.L. (Eds.). Biomaterials for tissue engineering applications. Vienna: Springer, 2011. p.179207.

YE, Q.; OHSAKI, K.; LI, K. et al. Histological reaction to hydroxyapatite in the middle ear of rats. Auris Nasus Larynx, v.28, p.131-136, 2001. 